\title{
Mind the (new) gap: a selective survey of current law and society research in the Netherlands
}

\author{
Marc Hertogh \\ University of Groningen
}

\begin{abstract}
This article presents a selective survey of current law and society research in the Netherlands. After a brief historical sketch, it focuses on contemporary Dutch studies on legal effectiveness and several studies on courts and dispute resolution. Based on a review of both fields, I identify two important trends in Dutch law and society research. The first trend is that, since the I970s, most researchers have been interested in 'old gap studies', which primarily focus on the efficacy of law. In recent years, however, public opinion in the Netherlands has become increasingly critical of the Dutch justice system. I argue that this has generated a second trend in Dutch law and society research, which I refer to as "new gap studies. Unlike traditional gap studies, their primary focus is not the efficacy but the legitimacy of law. In the final section, I draw several general conclusions and I look forward to the future of law and society research in de Netherlands.
\end{abstract}

\section{Introduction'}

Writing in the late I96os, the Dutch legal scholar Glastra van Loon (I968, pp. 5I-54) announced that 'sociology of law is beginning to come to life in the Netherlands' and slowly 'getting off the ground and above sea level'. Only some fifteen years later, Abel (I985, p. I7) observed that '[i]t is quite possible that the concentration of Dutch speaking socio-legal scholars is greater, in proportion to the population they are studying, than that in any other country'. At present, sociology of law is well institutionalised in all nine faculties of law in the Netherlands, with its own staff, its own research projects and a place in the curriculum. At six universities, there are professorships in sociology of law, while at other faculties there are (also) chairs in related fields like legal theory, legal anthropology and the administration of justice. In addition, law and society research is conducted at (and commissioned by) non-academic research centres like the Council for the Judiciary and the Research and Documentation Centre (WODC) of the Dutch Ministry of Justice. Painted in broad brush strokes, law and society research in the Netherlands has three distinctive characteristics. First, 'most subjects and perspectives characteristic of sociology of law internationally are well represented in Dutch research' (Griffiths, 2007). Second, Dutch sociology of law is more closely related to law than the social sciences. Over the years, this has created an 'osmosis' (Hoekema, I985, p. 32) between sociology of law and the legal sciences. Finally, in most law and society studies, '[t]he impetus for research tends to be practical rather than theoretical' (Abel, I985, p. 5). Consequently, sociology of law in the Netherlands has produced many important empirical studies, but rather few grand theories (Schwitters, I996, p. 530).

In this article, I present a selective survey of current law and society research in the Netherlands. The review covers both 'sociology of law' and 'socio-legal studies', but excluded are

I I would like to thank the editors of this journal for their comments on an earlier draft. In writing this essay, I also greatly benefited from several earlier reviews of law and society research in the Netherlands (see Abel, I985; Glastra van Loon, I968; Griffiths, 2007; Hoekema, I985; I990; Schwitters; 1996). 
legal anthropology, criminology and legal psychology. Historically, the development of sociology of law in the Netherlands is closely connected to anthropology of law. The roots of Dutch legal anthropology lie in the so-called adat law school, which in colonial times was aimed at recording the local customary laws of what is now Indonesia. Anthropology of law has, however, already been covered by several other comprehensive reviews (see Griffiths, 1985; von Benda-Beckmann and von Benda-Beckmann, 2002; Böcker, van Rossum and Weyers, 2009). Criminology is fairly well established in the Netherlands as well (Van Swaaningen, 2006). Yet, historically, there have been few institutional contacts between Dutch legal sociologists and criminologists. Dutch criminologists have their own professional association and they publish in their own specialised journals. To a large extent the same holds true for legal psychology. The choice of studies in this article makes no claim to comprehensiveness. Instead, I focus on those studies from the past two decades which may also be relevant for law and society scholars outside the Netherlands, but which (for the most part) have not been discussed in the international literature before. Moreover, the selected studies are well suited to assess the strengths and weaknesses of the field. After a brief historical sketch of the development of law and society research in the Netherlands (section II), the article focuses on two fields. First, I discuss several Dutch studies on legal effectiveness. This section includes an evaluation study of anti-discrimination law and a study of the effects of the lifting of the brothel ban in the Netherlands (section III). Next, I take a closer look at Dutch studies on courts and dispute resolution. This section covers studies which focus on the events before, during and after a court procedure (section IV). Based on a review of both fields, I identify two important trends in Dutch law and society research (section V). The first trend is that, since the I970s, most researchers have been interested in 'old gap studies', which primarily focus on the efficacy of law. In recent years, however, public opinion in the Netherlands has become increasingly critical of the judiciary and the functioning of the Dutch justice system in general. I argue that this has generated a second trend in Dutch law and society research, which I refer to as 'new gap studies'. Unlike traditional gap studies, their primary focus is not the efficacy but the (perceived) legitimacy of law. In the final section, I draw several general conclusions and I look forward to the future of law and society research in the Netherlands (section VI).

\section{Law and society research in the Netherlands: a brief history ${ }^{2}$}

Starting in the I960s, there are roughly three stages of development in Dutch law and society research, which I will refer to as idealism, criticism and realism.

\section{Idealism (1965-1980)}

During the I960s, changing ideas about the relationship between law and society led to the emergence of sociology of law as a separate discipline in the Netherlands. At this time, an instrumental view of law ('law as a means of social control') became increasingly popular among lawyers and policy-makers. After the World War II, the Netherlands was rapidly transformed into an industrial nation, by means of government intervention. Similarly, the aim in mind of the founding fathers of Dutch sociology of law, was 'to turn law, wherever possible, into an instrument for effective and legitimate government action' (Hoekema, I985, p. 35). There was also a second development which contributed to the development of Dutch sociology of law. In the I960s, there was a feeling that 'increasing welfare, mobility and secularization put the legitimacy of the foundations of the social order and the traditional role of the lawyer into doubt' (Hoekema, I990, p. 517). In the Dutch press, much attention was paid to several court-room scandals which

2 For an extended bibliography of Dutch socio-legal publications, see Hoekema (I990); Hertogh and Weyers (2OII). 
were labelled as 'class justice'. Moreover, public opinion surveys showed that nearly half of the population believed that judges had double standards. All this seemed to indicate 'a perilous extent of distrust in the due course of justice as a whole' (Hoekema, I985, p. 34). These events led a group of prominent law professors to write a pamphlet advocating the development of sociology of law. In their view, the re-establishment of faith in the legal system could only be expected to take place 'if the very institution of state authority had a new source of rationality and objectivity: the (social) sciences' (p. 34) Their initiative was successful and most faculties of law decided to establish a professorship in sociology of law.

One of the first topics investigated by Dutch sociologists of law was the attitude of ordinary citizens towards law. Vinke, a professor of tax law in Leiden, studied what the general public knew and thought about taxes, the burden of taxation and the conduct of the Revenue Department. His research played an important role in an early collaborative cross-cultural effort by European scholars - the so-called Knowledge and Opinion about Law (KOL) studies (Podgorecki, Kaupen, van Houtte, Vinke and Kutchinsky, I973). The initial wave of institutionalisation of sociology of law was strengthened even further in the I97os. Sparked by the cultural revolution of I968, there was growing support for a 'forum concept of law'. Law should provide a forum 'where all society's individuals and groups could engage in a free dialogue, unhampered by power relations' (Hoekema, I985, p. 37). One of the tasks of sociology of law to emerge from this concept of law was to show which elements of the social structure keep certain groups of people from participating in the dialogue. In this period, 'access to law' became the dominant theme. A widely discussed study at the time focused on the legal problems of ordinary people and their experiences in seeking the help of lawyers and other advice agencies (Schuyt, Groenendijk and Sloot, 1976). The project explained inequality of access to legal services and discussed the possibilities of government intervention to rectify the situation. This research stimulated a large amount of related research on the subject of legal service with a substantial political impact. In a different area, Dutch law and society scholars also played an important role in achieving international recognition for the concept of legal pluralism. In 1978, Dutch anthropologists and other scholars were actively involved in establishing the international Commission on Folk Law and Legal Pluralism.

\section{Criticism (1980-1990)}

In I98I, the Dutch and Flemish law and society association (Vereniging voor de SociaalWetenschappelijke Bestudering van het Recht; VSR) was established. During the I980s, most sociologists of law remained focused on the study of practical problems of the welfare state. However, as the financial-economic situation quickly deteriorated, the optimism about the possibilities for bringing about social change by way of law was undermined. Also, there was now much less optimism about the possibility of creating an open, participatory, grass-roots democracy. First, there was disappointment and growing criticism about the fact that the instrumental approach much promoted in the previous years failed to bring about the desired effects. Second, research into the effects of the new system of legal aid and forms of participation showed that many people (and especially minority groups) hardly benefited at all from these new facilities.

As a result, attention was again directed at the closed nature of social structures and processes of public decision-making. In Dutch sociology of law, many scholars redirected their attention towards the power of public bureaucracies. One example is a large research programme lead by Hoekema aimed at studying processes of 'horizontal government' or 'negotiated decision-making'. Despite these names, many of these processes actually refer to 'a system of domination by a limited elite' (Hoekema, I990, p. 523). One other related research theme was the way in which front-line officials in public bureaucracies apply (administrative) laws. Many of these studies were inspired 
by Kagan's (1978) work on different 'modes of rule application' and Lipksy's (I980) work on 'streetlevel bureaucrats'. Empirical studies covered, for instance, the work of officials in welfare agencies, regulatory agencies and in local agencies for public housing. An important general finding of these studies was that public officials are not only concerned with applying the official rules, but their work is equally influenced by their own goals and ambitions which are often translated into informal rules of thumb.

In these years, two other important fields of interest in Dutch law and society research were immigration related issues (including the application of asylum law and discrimination against immigrants) and courts and litigation (including the recruitment of judges, different means of conflict resolution, and the mobilisation of law). Articles on these and other subjects were also frequently published in Recht der Werkelijkheid (Social Reality of Law), the scientific journal of the Dutch and Flemish law and society association, which was established in 1986.

\section{Realism (1990 - present)}

Whereas in the I970s and I980s sociology of law became well institutionalised in Dutch universities, there was some retrenchment in the I990s. Although sociology of law is still present in most law faculties, some faculties no longer have (full-time) professorships. Starting in the I9gos, there was also growing competition for sociology of law (both in terms of student numbers and in terms of research funding) from other, related, disciplines like criminology, public administration, legal psychology, and law and economics. In recent years, Dutch law and society scholars have continued to publish a considerable number of books, articles and research reports. However, unlike the work in the I970s and I980s, most contemporary research is no longer conducted with a clear ideological or political agenda.

Each year, the aforementioned Dutch/Flemish law and society journal publishes a special issue. These issues, some of which are published in English, are a good illustration of the diversity of subjects covered by Dutch law and society scholars. Their (translated) titles include: After the Verdict, Regulating Physician-Negotiated Death, Ordinary Citizens in the Courtroom, Self-Regulation, In Lawyers' Circles, Safety, Trust and Good Governance, Explorations in Legal Cultures and Reconsidering Max Weber's Concept of Domination. Also, in recent years no fewer than five different Dutch textbooks on sociology of law have been published. These include a book which introduces important themes from the literature through the lens of different concepts of legality (Hoekema and Van Manen, 2000); the fourth edition of a large collection of some of the most influential contributions to the international law and society literature, translated into Dutch and accompanied by a new introduction and conclusion (Griffiths and Weyers, 2005); two general introductions to sociology of law (Schwitters, 2008; Huls, 2009); and a book which aims to present the 'state of the art' of Dutch law and society research for a general audience (Hertogh and Weyers, 20II).

In this article, I focus on two important fields of contemporary research: Dutch studies on legal effectiveness and Dutch studies on courts and dispute resolution.

\section{Dutch studies on legal effectiveness}

Griffiths (2003, p. I3) has argued that the familiar approach to legislative effect is 'instrumentalism'. This (top-down) approach considers a legislated rule simply as a tool in the hands of a policy-maker who aims to realise some sort of social change. Moreover, the complex relationship between a rule and its social effects is conceived of in the instrumentalist paradigm as a straightforward causal one. By contrast, most Dutch research into the effects of legal rules 'has tended to reject the instrumentalist paradigm and to emphasise the importance of the social context within which rule following occurs, as well as the variety of nonlegal norms that are present' (Griffiths, 2007). 
Many of these (bottom-up) studies make use of the idea of 'semi-autonomous social fields' (Moore, I973). In the Dutch literature, two main theoretical approaches to legal effectiveness may be distinguished: the 'social working approach' (Griffiths, 2003) and the 'communicative approach' (Zeegers, Witteveen and Van Klink, 2005a). While the social working approach 'seeks to explain rule-following and does not consider symbolic effects of direct relevance is this respect', the communicative approach 'stresses the importance of symbolic effects for the working of law and accuses the social working approach of failing to appreciate this importance' (Zeegers, Witteveen and Van Klink, 2005b, p. I). Dutch empirical research on legal effectiveness has concerned such varied subjects as the regulation of euthanasia and socially problematic medical behaviour, worker-protection legislation and the legal position of immigrants. Here, I focus on the effects of Dutch anti-discrimination law and the effects of the lifting of the brothel ban in the Netherlands. Both fields have frequently been the subject of empirical studies and this work is also representative of Dutch legal effectiveness research in general.

\section{Dutch anti-discrimination law}

In 1983 the principle of equal treatment and non-discrimination was introduced in Section I of the Dutch Constitution. This constitutional provision, however, works primarily between individual citizens and the state. In order to apply the equal treatment and non-discrimination norm to relationships between citizens, the Equal Treatment Act (hereafter the ETA) came into force in 1994. According to the ETA, unequal treatment is explicitly prohibited on grounds of gender, marital status, race, nationality, religion, belief, political opinion and hetero- or homosexual preference. It is forbidden to treat people differently on these grounds of discrimination in two main fields: in working relationships and in offering goods and services. The ETA provides for the establishment of an Equal Treatment Commission. The Commission is an independent semijudiciary body that investigates complaints about discrimination. Their rulings are not legally enforceable.

The effects of Dutch anti-discrimination laws, and in particular the ETA, have frequently been the subject of empirical research by law and society scholars. Havinga and her colleagues conducted the first evaluation study of this law in I999 (Asscher-Vonk and Groenendijk, I999), which seven years later was followed by a second evaluation study by Hertogh and his team (Hertogh and Zoontjens, 2006). Parts of both studies have also been published in English (Havinga, 2002; Hertogh, 2009). Rather than applying a top-down or instrumentalist approach, which concentrates on the issue of whether the objectives of policy-makers are realised, both studies rely on a bottom-up approach which focuses on the social meaning and effects of the legislation in relevant social fields. Moreover, both studies not only study the effects in situations of (legal) conflict, but also look at the effects of legislation in everyday practice.

In their study, Havinga and colleagues conducted telephone interviews with personnel managers and they interviewed managers in a number of financial service organisations, schools and housing societies. To investigate the level of societal support for anti-discrimination law, they interviewed representatives of unions and anti-discrimination bureaus as well as several organisations of addressees, like employers organisations. Havinga concluded (2002, p. 78) that although most respondents knew that the law existed, 'their knowledge about the content of the legislation was rather limited'. Very few of their respondents were familiar with important provisions of the law. This limited level of legal awareness is also reflected in the limited impact of anti-discrimination law in everyday practice. According to Havinga (p. 78), the Act 'did not give rise to a re-assessment of equal treatment in personnel management'. This means that, '[a]ll in all the general effects of the anti-discrimination laws in labour organisations are rather limited and restricted to a minority of these organisations' (p. 79). The general effects of these laws are most profound in large governmental organisations and least in small enterprises. Havinga and her team also found that, 
in general, the support for equal treatment is high and nearly everyone they interviewed endorsed it. Yet most people did not translate their support into action. Equal treatment was not high on the agenda of personnel managers in organisations and most interest groups did not consider it their task to monitor compliance with the legal provisions.

In accordance with the legal requirement that there should be a full evaluation of the ETA every five years, Hertogh and his team have conducted a second study (Hertogh and Zoontjens, 2006). Unlike the first evaluation, this study also included a national survey to find out how antidiscrimination law matters among the general public. In addition, several Commission rulings were selected for extensive case-studies, which included interviews with most of the parties involved and a study of the Commission files. To analyse how anti-discrimination law matters among legal professionals, telephone interviews were conducted with personnel managers, (labour) lawyers, judges, representatives of anti-discrimination bureaus, trade union officials and representatives from several interest groups. Moreover, a number of Commission rulings were selected and interviews were conducted with some of the legal professionals who were involved in these cases. Hertogh and colleagues concluded that although a large majority of the general public $(76 \%)$ knows about the existence of the ETA, their knowledge about specific elements of the Act is rather limited. First, not all legal grounds for discrimination were equally known to them. Second, most respondents did not know in which fields the ETA applies and only ro per cent of them knew that the ETA can be applied to the dismissal of an employee. Finally, a large majority of respondents ( $85 \%$ ) did not know how to file a complaint with the Commission. The level of knowledge among legal professionals was higher, with the exception of the personnel managers participating in the study.

According to Hertogh and colleagues, there is a fairly high level of indifference for nondiscrimination law among the general public. Although 58 per cent of all respondents thought their own knowledge of the law was (very) poor, nearly two-thirds of them (65\%) were not interested in more information about the Act. Also, $5 \mathrm{I}$ per cent thought that it was (totally) unimportant to know about the content of the Act or were completely 'neutral' about the subject (Hertogh, 2009, p. 230). Although most ordinary citizens and legal professionals agreed with the general principle of legal equality, there was limited support for official non-discrimination law. For many people it is not anti-discrimination law that defines their understanding of equality, but rather their own idea of equality which colours their attitude towards law. In the end, their support for non-discrimination law depends on their personal evaluation: 'How much will the legal concept of equality contribute to their own idea of legal equality?' (p. 237).

\section{Lifting the ban on brothels in the Netherlands}

In 2000, after a long period of social and political debates, the general ban on brothels was lifted in the Netherlands and the relevant sections were removed from the Dutch penal code. This means that prostitution by adult prostitutes is legal, provided that they do their work on a voluntary basis and possess the legal residence permit required for employment. 'In the eyes of the law, prostitution is interpreted as a (special) form of labour' (Daalder, 2007, p. 5). At the same time, this legislation was also intended to make it possible to crack down on involuntary prostitution and prostitution by minors. With this amendment of the law, legislation was adapted to an actually existing practice, in which the ban on brothels was not enforced, or hardly at all. One of the main official objectives underlying the legal change was to protect (and to improve) the social position of prostitutes. In order to assess the effect of the new laws, two evaluation studies have been conducted. The first evaluation study was carried out in 200I (Vanwesenbeeck, Höing and Vennix, 2002). For this study, face-to-face interviews were held with 230 prostitutes and 62 sex business owners. The second study was carried out five years later (Dekker, Tap and Homburg, 2006; Daalder, 2007). For this study, face-to-face interviews were conducted with 354 prostitutes and 49 
owners. Both studies allow us to paint a detailed picture of the knowledge and opinion of prostitutes regarding the lifting of the brothel ban.

In 200I, the level of awareness of the new legal situation among prostitutes was quite poor. Their most important sources of information were their boss ( $45 \%$ ); a local health care agency (39\%); and the media (26\%) (Vanwesenbeeck et al., 2002, p. 64). In 2006, some 60 per cent of the prostitutes interviewed were aware of the changes in the law. There were, however, several important differences between different sectors of the industry: in massage parlours the level of awareness was the highest (77\%) and in the escort business it was the lowest (40\%). Their level of legal knowledge was also related to their age: among I 8- and I9-year-olds, only 5 per cent were aware of the new laws, and among the group of 20- to 29 -year-olds, this was 58 per cent. Finally, Dutch prostitutes were best informed (75\%) and Thai prostitutes were the worst informed (83\% were not aware of legal changes) (Dekker et al.. 2006, p. 56).

A comparison of the two studies suggests that, over a period of five years, most prostitutes have become more sceptical about the lifting of the brothel ban (Vanwesenbeeck et al., 2002, p. 53; Dekker et al., 2006, p. 57). In 2006, nearly half (47\%) of the respondents were not in favour of the legal change (in 200I, this was only true for $17 \%$ ). Also, in 2006, half of the respondents did not agree that the position of prostitutes had improved (55\%; 2001: $20 \%$ ). In addition, they did not feel that they commanded greater respect (54\%; 200I: 45\%), nor that crime in the industry had gone down (48\%; 200I: $36 \%$ ). Finally, in 2006, three-quarters (73\%) thought it was understandable that prostitutes would try to evade the regulations (in 200I, this was true for $64 \%$ ). In the second evaluation in 2006, prostitutes were also asked how they thought the lifting of the brothel ban had affected their personal situation. Only I2 per cent felt that their position had (slightly) improved. Some 9 per cent thought that their position had both slightly improved and slightly worsened; but nearly one-third (31\%) felt that their position had become worse. Half (48\%) of the prostitutes interviewed felt that since the change in the law their personal position had not changed at all (Dekker et al., 2006, p. 58).

After the first evaluation in $200 \mathrm{I}$, it was concluded that it was still too early to make a proper assessment of the effects of the lifting of the ban on brothels. It was expected that if the legalisation would improve the social position of prostitutes, it would become more apparent after five years. However, one of the main conclusions of the second evaluation was that 'ii]n recent years, [...] the labour relations in the licensed sector have barely changed' (Daalder, 2007, p. 87). In general, prostitutes in 2006 are less satisfied with their earnings, they are less likely to declare their earnings to the tax authorities, and their independence has either gone down or remained the same. Moreover, 'the well-being of prostitutes is lower in all measured aspects than it was in 200I' (p. 87)

From a legal perspective, the Dutch prostitution sector has become a 'normal' business, with all the corresponding rights and obligations. According to the legislator, this also implies an important improvement of the social position of prostitutes. Both evaluation studies demonstrate, however, that in reality things are a bit more complicated. First, in much of the prostitution sector, the level of legal awareness is quite limited. Second, the sector itself does not agree with important elements of the law. Finally, apart from the amendment of the law itself, the social position of Dutch prostitutes also depends on other important factors like the socio-economic conditions of the industry and public attitudes towards prostitutes. The legislator aims to turn the prostitution business into a normal industry, yet many prostitutes themselves do not feel that being 'normal' will improve their position. While regular employment has advantages (including clear legal rights and duties and full entitlement to welfare provisions), they see the disadvantages (most notably their loss of anonymity, independence and earnings) as being greater. According to the researchers, it is a mistake to assume that an amendment of the law will lead to an immediate attainment of the 
goals intended by it. 'After all, the prostitution sector represents an age-old activity, with its wear of customs and conventions that will not change from one day to the next' (Daalder, 2007, p. 20)

\section{Dutch studies on courts and dispute resolution}

Much law and society research in the Netherlands is also concerned with the understanding of dispute processes. Studies have focused on, for instance, court procedures both in the highest and the lowest courts, administrative procedures, divorce, medical complaints, property disputes and inheritance disputes. In this article, I will take a closer look at three studies which focus on the events before, during and after a court procedure. These studies are frequently discussed in the Dutch socio-legal literature and both their methods and conclusions are representative of those of most other studies in this field.

\section{Paths to justice in the Netherlands}

Both in 2003 and 2009, Genn's British study Paths to Justice (I999) was replicated in the Netherlands. Both studies provide an overview of the 'landscape of disputes' as seen from the perspective of Dutch citizens. Here, I will focus on the latest study (Van Velthoven and Klein Haarhuis, 20Io). This study was based on two (Internet) surveys. The first 'screening' survey was conducted among some 5,000 respondents and investigated the extent to which citizens aged eighteen and over were faced with (potential) civil law and administrative law problems. The second 'problem-solving' survey was conducted among those respondents who had experienced one or more problems (in total well over 2,000 respondents). This survey asked the respondents to describe in detail, with respect to one problem, the steps that had been taken to achieve a resolution of the problem. According to the researchers, 'the issue of which of the available solution strategies is chosen by the person seeking justice is [...] a matter of weighing the expected benefits and costs involved in that strategy' (Summary, p. 2I6).

The 2009 study shows that, over a period of five years, 60.5 per cent of the citizens were faced with one or more justiciable problems. The frequency of problems for the population as a whole was on average I.9 problems per person. In 2009, the frequency of problems was some 20 per cent lower than in 2003. According to the researchers, this is largely due to the economic situation and to other social developments such as the start of a general aging of the population. In 2009, the largest contribution of problems was provided by problems experienced in connection with the purchase of products and services (26\%), problems at or connected with work (22.5\%), and problems related to money and ownership of immovable property (each $\mathrm{I} 3.2 \%$ ). According to the researchers, the chances of encountering problems are not the same for everyone. As the level of education increases, the number of problems per person goes up. Moreover, the relationship to the factor income can be considered as U-shaped: persons in the lowest and highest income groups experience more problems than persons with an average income.

The study also looked at which routes respondents have taken towards the resolution of disputes. A group of 52 per cent (the 'advised', to use Genn's term) requested advice or assistance from one or more expert persons or organisations; 42 per cent dealt personally with the problem (the 'selfhelpers'); and 6 per cent remained passive (the 'lumpers'). Compared to 2003, there were more 'advised' and fewer 'lumpers' and 'self-helpers'. Only with respect to a small minority of the problems (I $2.7 \%$ ) was a start made with official proceedings; legal proceedings were started with respect to 4.9 per cent of the problems, and in 7.8 per cent of the problems an extra-judicial procedure was initiated. In general terms, most respondents felt that the legal provisions were 'very satisfactory'. However, when asked whether the legal system operates equally for everyone, irrespective of whether someone is rich or poor, the average score was 2.9 (on a five-point scale). Furthermore, when asked whether access to the courts leads to a solution of the problem, the 
score was 3.I. Finally, the honesty and reliability of the legal profession scored no more than 3.0. Precisely those respondents who were faced with legal problems and actually had to deal with judicial agencies were the least positive.

\section{Having your day in a Dutch court}

Bruinsma (I999) has analysed eighty-five famous civil court cases from the Hoge Raad (the Dutch Supreme Court) from a 'consumer's perspective' on law; What are the real stories behind these cases and how do the parties themselves look back at their experiences? Based on in-depth interviews with many of the parties, Bruinsma and a team of students have written more elaborate reports on twenty-two selected cases. When they first approached the parties, not all of them were aware that their cases had formally ended. Especially in those cases in which an insurance company had acted on behalf of one of the parties, the initial parties were not always informed about the outcome of the case. Also, several parties suggested that once they entered the office of their lawyer, they were no longer actively involved. 'On the road to the Hoge Raad parties lose sight and control over their own case', according to Bruinsma (I999, p. I49). 3 Many people were also outraged about the way the facts were misrepresented in the official case. As a result, they were often not convinced by the final ruling of the court. Many people did not understand the final ruling either and were annoyed to find that a seemingly simple question had now been turned into a complex legal issue. Finally, in many cases the court did not manage to convince the losers that the winners were right. Consequently, most cases did not restore normal relationships between the two parties. Or, as one respondent commented in perhaps an extreme example of a more general phenomenon: 'A gun is cheaper than a court procedure. If I had to do it all again, I would buy a gun and shoot her' (Bruinsma, I999, p. I0).

Bruinsma argues that while for most lawyers a well-motivated decision of the Hoge Raad is a supreme example of law and justice, for most one-shotters it only reflects the language of legal mandarins which does not do justice to the real facts of their case (Bruinsma, I999, p. I69). Many of their respondents displayed a lack of understanding of the length and the complexity of legal procedures. Moreover, they were highly critical about the lawyers and the judges in their case. 'Litigation makes you rather cynical', according to one of the respondents (p. 170). Similarly, another respondent remarked: 'Of course there have to be certain rules of the game. But as long as those rules are put in words that may be interpreted in different ways, adjudication cannot be law' (p. 139). According to Bruinsma, people who have been to court themselves often begin with a (naive) high level of confidence in courts, but their confidence quickly decreases once they gain more experience.

\section{Compliance with court decisions in the Netherlands}

In the international law and society literature, compliance with (civil) court decisions is still a fairly understudied subject. In the early I990s, Van Koppen and Malsch (I99I) conducted a much-cited empirical study of the effects of court decisions in civil cases in the Netherlands. For this study, they contacted attorneys for all cases in three trial courts in which the plaintiff's claim had been granted in whole or in part in a final decision three years earlier $(N=970)$. They asked them to what extent the defendant complied with the judgment. Their results showed that plaintiffs had difficulty in collecting their awards. On average, only a little more than half the award was collected after three years. In 43 per cent of the cases, the plaintiff received full payment within the three-year period. In 35 per cent of the cases, the plaintiff received nothing at all. In the remaining 22 per cent of the cases, the plaintiff received partial payment. The most important

These and all other quotations from Bruinsma (I999) were translated by the author. 
reason for failure of payment (given in $75 \%$ of the cases) was lack of reasonable assets of the defendant. According to Van Koppen and Malsch, the literature on civil disputes routinely reports that plaintiffs win the vast majority of cases. However, this contention overlooks the execution phase of civil disputes. In the end, winning in court is often a pyrrhic victory because many winners (plaintiffs) do not succeed in collecting any money from the losers in court (defendants).

For many years, this was the only study available on the level of compliance with court decisions in the Netherlands. However, in 2009 a new pilot study was conducted (Eshuis, 2009; 2010). In total, this study covered 38I cases at two average trial courts (all cases had ended with a final decision three years earlier). In each case, the court file was studied and at least one of the parties involved participated in a survey. Also, more elaborate interviews were conducted with I83 respondents. This study recorded a compliance rate which was substantially higher than the first study. However, on closer inspection this could largely be attributed to the selection of cases. The first study included a high number of default judgments, which are associated with a low level of compliance, while friendly settlements - associated with a high level of compliance - were excluded. When the original selection of cases from the first study is replicated, the difference in outcome of both studies strongly decreases. Based on this new selection of cases, there was full compliance in 50 per cent of the cases (I99I: 43\%); there was no compliance in 26 per cent of the cases (I99I: 35\%); and there was partial compliance in 24 per cent (I99I: 22\%). While in I99I there was no (full) compliance in 57 per cent of the cases, in 2009 this was true for 50 per cent.

In theory, a court decision should convince the losing party that they were wrong and - ideally speaking - after the court case the relationship between the two parties should be fully normalised again. This study shows that, in relation to civil court procedures, both assumptions are not always fully materialised. Generally speaking, most losing parties who were interviewed in the study were not convinced by the court but felt that their arguments were completely ignored. Moreover, the results from this study show that, after the court case, an overwhelming majority of people are no longer in contact with the other party and are not willing to engage in any future relationships either. Finally, earlier research has suggested that those people who were interviewed immediately after a court case were more positive (and expressed more confidence in the justice system) than those who were interviewed at a later stage. According to Eshuis (2009), this effect may be explained by the fact that the first group still expect that their court decision will be fully complied with. However, as time goes by many of them come to realise that this is not always the case. As it turns out, those 'winners' whose court ruling was completely executed display more confidence in the justice system than those whose ruling was not fully executed. This implies that disappointing and negative experiences with the execution of court rulings are most likely to blame for the fact that the evaluation of the courts becomes less positive over time.

\section{Old and new gap studies: from efficacy to legitimacy of law}

Based on our brief discussion of the history of the discipline in the Netherlands and our review of contemporary studies on legal effectiveness and dispute resolution we can identify two important trends in Dutch law and society research, which I will refer to as 'old' and 'new' gap studies.

\section{Old gap studies: law in the books vs. law in action}

Since the I960s, much (Anglo-American) law and society research has focused on the 'gap problem'; the investigation of the 'gap' between the ideal of the law and the actual practices flowing from it (Abel, I980; Feeley, I976). This approach has been dominant in a wide variety of studies, including work on the impact of legislation; the degree of social change achieved by important court decisions; and numerous studies of the divergence of the actions taken by administrative officials from norms that were supposed to govern their behaviour (see Nelken, I98I). All these 
studies focused on the divergence between the 'law in the books' and the 'law in action', and these studies were directed by 'the belief that the gap, once revealed, could and should be eliminated' (Abel, I973, p. I88). However, the exclusive focus on 'gap studies' in law and society research soon became heavily criticised. According to its critics, this approach was built on implausible hypotheses about the way in which norms might be expected to affect conduct. Moreover, the legal goals themselves 'tend to be viewed as self-evident or easily identified and are posited without much ado' (Feeley, I976, p. 499). A second type of criticism was that these 'gap studies' may have been useful in the early years of the discipline, but no longer produce new and important findings. According to Abel, to study the efficacy of laws is essentially to pose a nonproblem'. In his view, '[w]e know in advance that they will be largely ineffective'; therefore 'how long can we preserve a pose of naive amazement?' (Abel, I980, p. 827)

Our review of the Dutch literature shows that - in the Netherlands - this criticism was not taken very seriously. Most studies were policy-oriented and were primarily interested in 'what works'. Consequently, studying the 'gap problem' has been the most dominant trend in Dutch law and society research. This was not only the case in the early years of the discipline, but the popularity of this approach continued (and was perhaps even stronger) throughout the I980s and I99os. This is also reflected in many of the studies which were discussed earlier in this article. Although both the evaluation of the ETA and the lifting of the brothel ban were not presented as instrumentalist studies, both studies primarily focused on the tension between the 'law in the books' and the 'law in action'. This is also true for the Dutch studies on courts and dispute resolution. The Dutch 'Paths to Justice' study analysed if the legal principle of access to justice also materialised in practice. Likewise, Bruinsma's study was aimed at analysing the degree of social change achieved by important court decisions. Finally, the studies on the level of compliance with court decisions concentrated on the gap between the decision of the court and the actual behaviour of the parties involved.

Studying the gap between the 'law in the books' and the 'law in action' continues to be a prominent feature of much law and society research in the Netherlands. In recent years, however, Dutch public opinion has become increasingly critical about the functioning of the judiciary and the justice system in general. This has resulted in a second trend in Dutch sociology of law. Some of the latest law and society research is not only interested in the efficacy of legal rules, but is also increasingly concerned about the (perceived) legitimacy of law.

\section{Contesting the legitimacy of the Dutch justice system}

For many years, public support for the justice system in the Netherlands has been stable and fairly unproblematic. In comparative studies, the Netherlands was usually considered one of the most law-abiding countries in Europe and international public opinion surveys suggested that the level of public confidence in the Dutch Supreme Court was remarkably high. In the past decade, however, public opinion surveys suggest that there is growing public criticism aimed at the Dutch judiciary (and at criminal courts in particular). According to the Netherlands Institute for Social Research (SCP), which reviewed all available datasets, there has been a strong decline in confidence between I98I and I999. While both in I98I (65\%) and in I990 (63\%) nearly twothirds of the Dutch population expressed a (very) high level of confidence in the justice system; in I999 this was only less than half (48\%) of the population (see Dekker and Van der Meer, 2007, p. I2). This trend seems to have been arrested by the end of the I9gos. According to the Eurobarometer, between 1997 and 2005 the level of trust in the Dutch legal system fluctuated between 5I and 64 per cent, with no clear trend (p. I4). Other surveys suggest that people are most critical about the lack of punitivity and responsiveness of the Dutch judiciary. For instance, nearly nine out of ten (87\%) people in the Netherlands (strongly) feel that crimes are being punished too lightly (Koomen, 2006, p. 4). Similarly, 76 per cent agree that 'nowadays, judges are 
too lenient' (Ettema, 2008, p. I6). The Dutch also feel that judges are isolated from society. There is a considerable majority for critical statements like these: 'Judges do not try hard enough to explain their decisions to the common man' ( $82 \%)$; 'Judges decide too often in a way unacceptable to the ordinary citizen' (6r\%); and 'The Dutch judge lives in an ivory tower' (48\%) (Elffers and De Keijser, 2008, p. 457).

These recent changes in the public opinion climate were accompanied by a number of controversial legal events. First, in the past decade there have been several widely publicised miscarriages of justice in the Netherlands. One of these cases is that of Lucia de Berk, a nurse jailed for life in 2003 for murdering seven patients and attempting to murder three more. ${ }^{4}$ During the trial, the prosecution claimed that most of the patients died as a result of 'medically unexplained' causes and in many of these cases Lucia was on duty 'noticeably often' when someone died. However, critical observers of the case felt that Lucia had been unjustly convicted. A protest group organised an online petition and a protest march outside the prison walls. Two of their members also submitted official presentations to a Dutch legal advisory committee, which examined selected closed cases and looked for evidence of errors in the police investigation. Following these and other actions, Lucia was released from jail in 2008 pending a review of the case. In April 20I0, after a retrial, she was officially acquitted. According to some observers, the acquittal marks one of the biggest miscarriages of justice in Dutch legal history.

A second noticeable event was the controversial hate speech trial of the Dutch far-right politician Geert Wilders. 5 In the autumn of 20I0, he faced five charges of inciting racial and religious hatred for his denunciations of Islam as fascist and demanding that the Koran be banned. At the start of the proceedings, Wilders denounced his trial as a 'political trial' and he stated that he had lost all confidence in the Dutch judicial system. Very unusually for the Netherlands, this trial was broadcast live on national television. During the trial there were reports in the media that one of the appeal court judges who ordered Wilders to stand trial had dinner with a potential witness, a Dutch expert on Islam. It was claimed that the judge had sought to convince him why Wilders had to be prosecuted. Following these reports, Wilders's lawyer asked to summon the witness but was refused. He then formally protested that the judges were biased against the defendant. His complaint was upheld by another judges' panel, which ordered a complete retrial with a new bench. This highly unusual decision meant that the trial had to be postponed for months. In the summer of 20II, Wilders was acquitted of all charges and the court ruled that his statements about Islam were 'acceptable within the context of public debate'.

\section{New gap studies: legal elite vs. general public}

The recent developments in the Dutch public opinion climate are also reflected in some of the latest law and society research in the Netherlands. While some researchers claim that the increasing criticism of the judiciary is proof of a 'legitimacy crisis', others argue that overall public support for the justice system remains relatively high. This debate has resulted in a rediscovery of the 'gap problem' in Dutch law and society research, albeit in a different form than in the past. Whereas traditional gap studies focused on the 'efficacy gap' of law, new gap studies are more interested in analysing a potential 'legitimacy gap'. Unlike traditional gap studies - which focused on the tension between 'law in the books' and 'law in action' - new gap studies focus on the gap between the 'internal legal culture' of the legal elite and the 'external legal culture' of the general public (see Friedman, I975, p. 223). In the past, the sociological analysis of the (perceived) legitimacy of

4 See, e.g., 'Dutch Nurse Acquitted of Being a Mass Murderer', New York Times, I4 April 20 ro.

5 See, e.g., 'Top Judge Says Wilders Undermines Judiciary', Radio Netherlands Worldwide, 24 October 20 Io; 'Geert Wilders Hate Speech Trial Collapses in The Netherlands', guardian.co.uk, 22 October 20Io; 'Geert Wilders Cleared of Hate Charges by Dutch Court', BBC News Europe, 23 June 20 I I. 
law has not been without problems (Hyde, I983). Moreover, compared to the long list of 'efficacy' studies, the latest trend in Dutch sociology of law is still in its infancy. There is, however, a growing interest for this subject among policy-makers, and the theoretical and empirical study of legitimacy has also become more popular in Dutch law and society research.

Weyers and Hertogh (2007) have, for example, analysed the most important empirical research from the past decade to assess the perceived legitimacy of acts associated with the Dutch Ministry of Justice. In their study, they have considered three dimensions of legitimacy: (a) the level of public trust, (b) the level of public satisfaction, and (c) the level of public acceptance of these acts. The general picture which emerged from their study is that the legitimacy of the justice system is no longer self-evident but has, instead, become 'structurally contested'. Rather than automatically accepting the decisions and rules of legal authorities as 'right' or 'proper', their findings indicate that the Dutch first need to be convinced by these legal authorities that they 'deserve' to rule. Other recent examples of this type of research include a number of 'legal consciousness' studies both in relation to legal equality (Hertogh, 2009; Oomen, 20II) and in relation to international human rights (Oomen, 2009); several studies on ordinary people's experiences with complaint procedures in administrative law (Laemers, de Groot-van Leeuwen and Fredricks, 2007; Winter, Middelkamp and Herweijer, 2007; De Waard, 20II); and a national 'legitimacy monitor' which aims to integrate a wide variety of public opinion surveys (Hendriks, van Ostaaijen and Boogers, 20II).

This focus on the 'new gap problem' is also reflected in some of the studies which were discussed earlier in this review. At closer inspection these studies not only focus on the efficacy, but also on the (perceived) legitimacy of the Dutch justice system. This is perhaps most clearly illustrated in Bruinsma's study. His study also focuses on the divergence between the legal perspective of judges and lawyers and the popular perspective of ordinary citizens. While most lawyers consider the famous court cases in his study as wonderful examples of splendid technical reasoning, the parties themselves often have a completely different recollection of the case:

'Whereas lawyers think about adjudication in terms of a legal pyramid with the Supreme Court as a sparkling star at the top, ordinary citizens who've made it all the way to the Hoge Raad tend to think of adjudication as a swamp in which you sink deeper with every next step.' (Bruinsma, I999, p. I69)

According to Bruinsma (p. I49), 'the bigger the gap between the moral judgment of the case by the parties themselves and the legal judgment by lawyers and judges; the higher the level of alienation from law'. A similar perspective is also present in most of the other studies. For example, in studies on the effects of Dutch anti-discrimination law it was established that the level of social support for this legislation depends on the 'gap' between the legal definition of equality and people's own ideas of equal treatment. Likewise, in evaluation studies on the lifting of the brothel ban in the Netherlands, most prostitutes completely disagreed with important elements of the new laws. Considering this 'gap' between what law-makers think is needed to improve the social position of prostitutes and the ideas of the concerned prostitutes themselves, three-quarters of those prostitutes who were interviewed thought it was understandable that their colleagues would try to avoid the legal regulations as much as possible. Finally, the legitimacy of the justice system was also an important underlying issue in the Dutch 'Paths to Justice' study and the study on the level of compliance with court decisions.

\section{Full circle}

Although the recent law and society studies on the gap between the legal elite and the general public were referred to as 'new' gap studies, strictly speaking this approach is not so new at all. The present 
focus in the Dutch media on miscarriages of justice and the increasing criticism of the judiciary are quite reminiscent of the focus on court-room scandals and the concern for 'class justice' in the I96os (prior to the emergence of traditional gap studies). Similarly, the development of a 'legitimacy crisis' is covered not only in some of the latest textbooks (Schwitters, 2008; Huls, 2009), but was also an important topic in some of the earliest examples of Dutch law and society research (Hoekema, I97I; Schuyt, I97 I) and in some of the first KOL studies (Podgorecki et al., I973). In this way, law and society research in the Netherlands has almost come full circle. Rather than a radical break with the past, the development of 'new' gap studies demonstrates a strong continuity with law and society research from the early years of the discipline. However, there are also several important differences between the two types of research. First, whereas most (KOL) studies in the I960s were primarily based on mass public-opinion surveys, contemporary examples of legitimacy research also include more advanced ethnographic studies which are interested in the theoretical development of relevant concepts and ideas. Second, while in the Ig6os law professors and other members of the legal elite contributed to the end of the 'legitimacy crisis' (by advocating the establishment of sociology of law), at present the legal elite is considered part of the problem rather than the solution. Finally, in addition to the increasing mobility and secularisation of citizens, contemporary studies also focus on how the legitimacy of the national justice system is affected by new developments like globalisation, multiculturalism and the increasing role of the European Union.

\section{Conclusion}

In this article, I have presented a selective survey of current law and society research in the Netherlands. Although its present popularity and institutional position may be weaker than in the I970s and I980s, this survey demonstrates that after some fifty years Dutch sociology of law is still alive and kicking. Moreover, the studies which were discussed in this review allow us to draw several general conclusions which may also be relevant for law and society scholars outside the Netherlands (see Hertogh and Weyers, 20II, p. I4). First, these studies illustrate the 'social' character of law. Law does not exist separate from (or above) society, but is part of society. The social meaning of law is not determined by the text of court rulings, new laws or policy documents, but by the human relations at a government department, an enforcement agency or a court building. Second, these studies also demonstrate the 'pluralistic' character of law. In many different fields, official legal norms have to compete with non-state law. In businesses, organisations, cultural communities and in other social contexts, these informal rules are considered equally important as official law. Finally, both the 'social' and the 'pluralistic' character of law imply that law does not always produce the consequences that the judge or the law-maker had in mind. Most Dutch studies show that the level of compliance with, for instance, legislation is not determined by the ambitions of the legislator, but rather by the degree in which these rules correspond to the characteristics of the social field it aims to regulate.

This review has also discussed several weaknesses of current law and society research in the Netherlands. Both in the past and the present, the most important trend in the Dutch literature has been a strong focus on the 'old gap problem'. Writing more than thirty years ago, Abel (I980) pointed to a similar trend in American law and society research. In his view, this approach may have been useful in the early days of the discipline, but it no longer generates any new findings: '[O]ur field is running so smoothly along familiar tracks that the questions and answers have begun to sound a comfortable, but rather boring "clackety-clack"'(p. 805). From this he concluded that the original paradigm of law and society research was exhausted and it was time for something new. 
Three decades later, Abel's criticism seems more true than ever in the Netherlands. Although early gap studies have made an important contribution to the development of Dutch sociology of law, focusing on the fact that the 'law in the books' does not equal 'the law in action' is no longer sufficient to distinguish law and society research from other (legal) disciplines. Therefore, the future of the discipline in the Netherlands depends on the development of a different paradigm for law and society research.

I have argued that a second trend in the literature - the development of 'new gap studies' which focus on the legitimacy of law - may be a promising alternative direction for Dutch law and society research. Returning to one of the earliest topics in the field, these studies can benefit from half a century of experience with this type of research. Moreover, public concern about a 'legitimacy crisis' of the justice system is not limited to the Netherlands, but is also a major theme in other European countries (see, e.g., Parmentier, Vervaeke, Doutrelepont and Kellens, 2003; Van de Walle and Raine, 2008; Hertogh, 20II). This shows that the future of law and society research in the Netherlands is no longer a national issue, but one which is closely connected to the future development of sociology of law in the rest of Europe.

\section{References}

ABEL, Richard (1973) 'Law Books and Books About Law', Stanford Law Review 26: 175-228.

ABEL, Richard (I980) 'Redirecting Social Studies of Law', Law \& Society Review I4: 805-829.

ABEL, Richard (1985) 'Sociology of Law in the Dutch-Speaking Countries', in J. Van Houtte (ed.),

Sociology of Law and Legal Anthropology in Dutch Speaking Countries. Dordrecht: Martinus Nijhoff

Publishers, 5-I9.

ASSCHER-VONK, I. and GROENENDIJK, C. (eds) (I999) Gelijke behandeling: regels en realiteit. Een juridische en

rechtssociologische analyse van de gelijke-behandelingswetgeving. Den Haag: SdU Uitgevers.

вÖCKer, Anita, van rossum, Wibo and Weyers, Heleen (eds) (2009) Legal Anthropology from the Low

Countries (Special Issue Recht der Werkelijkheid). Amsterdam: Reed Business.

Bruinsma, Freek (I999) De Hoge Raad van onderen, 2nd edn. Deventer: W. E. J. Tjeenk Willink.

DAALDER, A. J. (2007) Prostitution in the Netherlands Since the Lifting of the Brothel Ban (WODC). Den Haag:

Boom Juridische Uitgevers

DEKKER, Helga, TAP, Ruud and HOMBURG, Ger (2006) Evaluatie opheffing bordeelverbod. De sociale positie van prostituees 2006. Amsterdam: Regioplan.

DEKKER, Paul and VAN DER MEER, Tom (2007) Vertrouwen in de rechtspraak nader onderzocht. Den Haag:

Sociaal en Cultureel Planbureau.

elfFers, Henk and DE KeIJSER, Jan (2008) 'Different Perspectives, Different Gaps. Does the General

Public Demand a More Responsive Judge?', in H. Kury (ed.), Fear of Crime - Punitivity. New

Developments in Theory and Research. Bochum: Universitätsverlag Brockmeyer, 447-70.

ESHUIS, Roland (2009) De daad bij het woord. Het naleven van rechterlijke uitspraken en schikkingsafspraken.

Den Haag: Raad voor de Rechtspraak.

ESHUIS, Roland (20I0) 'Een verliezer is geen winnaar. De naleving van civiele rechtspraak, I 5 jaar na

Van Koppen en Malsch', Recht der Werkelijkheid 31: 6-20.

ETTEMA, Ageeth (2008) De Staat van het Recht anno 2008. Amsterdam: TNS Nipo.

FEELEY, Malcolm (I976) 'The Concept of Laws in Social Science: A Critique and Notes on an Expanded

View', Law \& Society Review I0: 497-523.

friedman, Lawrence (1975) The Legal System: A Social Science Perspective. New York: Russell Sage Foundation.

Genn, Hazel (I999) Paths to Justice: What People Do and Think About Going to Law. Oxford: Hart Publishing. 
GLASTRA VAN LOON, Jan F. (I 968) 'Sociology of Law in The Netherlands', in R. Treves and J. F. Glastra van Loon (eds). Norms and Actions. National Reports on Sociology of Law. The Hague: Martinus Nijhoff, $5 \mathrm{I}-65$.

GRIFFITHS, John (I985) 'Current Legal Anthropology in the Netherlands: Trend Report', in J. van Houtte (ed.), Sociology of Law and Legal Anthropology in Dutch Speaking Countries. Dordrecht: Martinus Nijhoff Publishers, I05-I48.

GRIFFITHS, John (2003) 'The Social Working of Legal Rules', Journal of Legal Pluralism 48: I-84. GRIFFITHS, John (2007) 'Netherlands and Flanders', Encyclopedia of Law \& Society: American and Global Perspectives. Sage Publications (e-book). Available at: www.sage-ereference.com/view/law/n487. $\mathrm{xml}$.

GRIFFITHS, John and WEYERS, Heleen (eds) (2005) De sociale werking van recht. Een kennismaking met de rechtssociologie en rechtsantropologie. Nijmegen: Ars Aequi Libri.

HAVINGA, Tetty (2002) 'The Effects of Anti-Discrimination Law in the Netherlands', International Journal of the Sociology of Law 30: 75-90.

HENDRIKs, F., VAN OSTAAIJEN, J. and BoOgers, M. (20I I) Legitimiteitsmonitor Democratisch Bestuur. Naar een metamonitor van de legitimiteit van het democratisch bestuur in Nederland. Den Haag: Ministerie van Binnenlandse Zaken en Koninkrijksrelaties.

HERTOGH, Marc (2009) 'What's in a Handshake? Legal Equality and Legal Consciousness in the Netherlands', Social \& Legal Studies I 8: 22 I-39.

HeRTOGH, Marc (20I I) 'Loyalists, Cynics and Outsiders: Who Are the Critics of the Justice System in the UK and the Netherlands?', International Journal of Law in Context 7: 3I-46.

Hertogh, Marc and weyers, Heleen (eds) (20II) Recht van onderop. Antwoorden uit de rechtssociologie. Nijmegen: Ars Aequi.

Hertogh, Marc and zoontjens, P. (eds) (2006) Gelijke behandeling: principes en praktijken. Evaluatieonderzoek Algemene wet gelijke behandeling. Nijmegen: Wolf Legal Publishers.

HOEKEMA, André (I97I) Vertrouwen in de justitie. Resultaten van een vergelijkend onderzoek. Alphen aan den Rijn: Samsom Uitgeverij.

hoekema, André (1985) 'Dutch Trends in the Sociology of Law in the Past Two Decades', Netherlands' Journal of Sociology 2: 32-50.

HoEkema, André (I990) 'Sociology of Law in the Netherlands in the 8os', in V. Ferrari (ed.), Developing Sociology of Law: A World-Wide Documentary Enquiry. Milano: Dott. A. Giuffré Editore, 509-570.

hoekema, André and van manen, N. (2000) Typen van legaliteit: ontwikkelingen in recht en maatschappij. Kluwer: Deventer.

HuLs, Nick (2009) Actie en reactie. Een inleiding in de rechtssociologie. Den Haag: Boom Juridische uitgevers.

HYDE, Alan (1983) 'The Concept of Legitimation in the Sociology of Law', Wisconsin Law Review: 379-426.

KAGAN, Robert (1978) Regulatory Justice: Implementing a Wage-Price Freeze. New York: Russell Sage Foundation.

коOMEn, Mireille (2006) Lekenparticipatie in de strafrechtspraak. Het beeld van de Nederlandse bevolking. Amsterdam: TNS Nipo.

Koppen, Peter van and malsch, Marijke (I99I) 'Defendants and One-Shotters Win After All: Compliance with Court Decisions in Civil Cases', Law \& Society Review 25: 803-820.

LAEMERS, M., DE GROOT-VAN LEEUWEN, L. and FREDRIKS, R. (2007) Awb-procedures vanuit het gezichtspunt van de burger. Stand van zaken in theorie en eerder onderzoek. Den Haag: Boom Juridische uitgevers.

LIPSky, Michael (I980) Street-Level Bureaucracy. Dilemmas of the Individual in Public Services. New York: Russell Sage Foundation.

MOORE, Sally Falk (I973) 'Law and Social Change: The Semi-Autonomous Social Field as an Appropriate Subject of Study', Law \& Society Review 7: 719-46. 
Nelken, David (I98I) 'The "Gap Problem” in the Sociology of Law: A Theoretical Review', Windsor Yearbook of Access to Justice I: 35-6I.

oomen, Barbara (2009) 'Justice Mechanisms and the Question of Legitimacy: The Example of Rwanda's Multi-layered Justice Mechanisms', in K. Ambos, J. Large and M. Wierda (eds), Building a Future on Peace and Justice: Studies on Transitional Justice, Peace and Development. Berlin: Springer Verlag, I75-202.

oomen, Barbara (20I I) 'Between Rights Talk and Bible Speak: The Implementation of Equal Treatment Legislation in Orthodox Reformed Communities in the Netherlands', Human Rights Quarterly 33: $175-200$.

parmentier, S., vervaeke, G., Doutrelepont, R. and kellens, G. (eds) (2003) Public Opinion and the Administration of Justice. Popular Perceptions and Their Implications for Policy-Making in Western Countries. Brussels: Politeia.

PODGORECKI, A., KAUPen, W., van hOUTTE, J., VINKE, P. and KUTChinsky, B. (I973) Knowledge and Opinion about Law. London: Martin Robertson.

schuyt, C. (I97I) Rechtssociologie. Een terreinverkenning. Rotterdam: Universitaire Pers.

SCHUYT, C., GROENENDIJK, C. and sLOOT, B. (I976) De weg naar het recht. Een rechtssociologisch onderzoek naar de samenhang tussen maatschappelijke ongelijkheid en juridische hulpverlening. Deventer: Kluwer.

schwitters, Rob (ig96) 'De rechtssociologie in Nederland en België', In J. Griffiths (ed.), De sociale werking van recht. Een kennismaking met de rechtssociologie en rechtsantropologie. Nijmegen: Ars Aequi Libri, 5I7-33.

SCHWITTERS, Rob (ed.) (2008) Recht en samenleving in verandering. Inleiding in de Rechtssociologie. Deventer: Kluwer.

van DE Walle, Steven and RaINe, John W. (2008) Explaining Attitudes Towards Justice Systems in the UK and Europe (Ministry of Justice Research Series 9/08). London: Ministry of Justice.

VAN SWAANingen, René (2006) 'Criminology in the Netherlands', European Journal of Criminology 3: 463501 .

vanwesenbeeck, Ine, höIng, Mechtild and vennix, Paul (2002) De sociale positie van prostituees in de gereguleerde bedrijven, een jaar na de wetswijziging. Utrecht/Den Haag: Rutgers Nisso Groep/ WODC, Ministerie van Justitie.

velthoven, B. van and KLEIN HAARHUIS, C. M. (20I0) Geschilbeslechtingsdelta 2009: over verloop en afloop van (potentieel) juridische problemen van burgers (with English Summary) (WODC). Den Haag: Boom Juridische Uitgevers.

von benda-Beckmann, Franz and von benda-beckmann, Keebet (2002) 'Anthropology of Law and the Study of Folk Law in the Netherlands after 1950', in H. Vermeulen and J. Kommers (eds), Tales from Academia. History of Anthropology in the Netherlands. Saarbrücken: Verlag für Entwicklungspolitik Saarbrücken, 695-73I.

WAARD, B. de (ed.) (20II) Ervaringen met bezwaar. Onderzoek naar de ervaringen van burgers met de bezwaarschriftprocedure uit de Algemene wet bestuursrecht. Den Haag: Boom Juridische uitgevers.

WEYERS, Heleen and HERTOGH, Marc (2007) Legitimiteit betwist. Een verkennend literatuuronderzoek naar de ervaren legitimiteit van het justitieoptreden. Groningen: Rijksuniversiteit Groningen.

WINTER, H., MidDELKAMP, A. and HERWEIJER, M. (2007) Klagen bij bestuursorganen. Evaluatieonderzoek naar de klachtbehandeling door bestuursorganen. Den Haag: Boom Juridische uitgevers.

zeEgers, Nicolle, Witteveen, Willem and van KLInK, Bart (eds) (2005a) Social and Symbolic Effects of Legislation Under the Rule of Law. Lewiston: Edwin Mellen Press.

zeEgers, Nicolle, witTeveen, Willem and van kuink, Bart (2005b) 'Introduction. The Social and Symbolic Working of Legal Rules' in N. Zeegers W. Witteveenand B. van Klink (eds) (2005) Social and Symbolic Effects of Legislation Under the Rule of Law. Lewiston: Edwin Mellen Press, I-5. 